\section{Reference and Information Literacy in the Community College Library}

\author{
Chelsea Contrada \\ Chelsea Contrada, MSLIS, is OER and Outreach Librarian, \\ Springfield Technical Community College Library.
}

Correspondence concerning this column should be addressed to Sarah LeMire; e-mail: slemire@tamu.edu.
Library workers from libraries of all types can struggle with the challenges of juggling instructional responsibilities with other assigned duties. Library context can play a key role in the resources available to mitigate these challenges. In this article, Chelsea Contrada discusses information literacy instruction in a community college library context and how that context influences her approach to library instruction. She articulates some of the unique aspects of instruction in community colleges and how community college librarians take a different approach than many of their peers in fouryear colleges and universities. Contrada makes a strong case for increased collaboration across library type and more robust opportunities for professional development and engagement for community college librarians._Editor

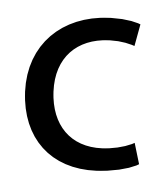

ommunity colleges play an important role in the education system. While a college education has seemingly become vital for career success, it is still a privilege that is inaccessible to many. Community colleges offer students of any background, regardless of socioeconomic status, a chance to experience higher education and learn in an accepting and open environment. Community college students, faculty, and librarians often face stigma, as there are many negative stereotypes associated with two-year schools. Community and junior colleges are accused of being less academically challenging than fouryear schools or of being more focused on trades and careers than on academics, but these are misconceptions. The community college provides opportunity to those who need their college experience to be flexible and affordable. They level the playing field so that a college education is something that everyone has the chance to experience.

Community college libraries are unique institutions that combine service and learning through a lens of equity and social justice. They provide access to the resources and services that students need to be academically successful, whether it be technology assistance, research help, computer access, or just a safe and quiet place to study. But are access, service, and safety not the mission of all libraries? This article will share an insider's perspective of community college libraries in an attempt to clear up common misconceptions and explore not only how community college libraries and librarians differ from their other academic colleagues, but also reveal that we all face the same fundamental triumphs and challenges. 


\section{COMMUNITY COLLEGES: AN OVERVIEW}

Community colleges (or "junior colleges" as they were referred to early on) began in the early twentieth century with the objective of creating a more highly skilled workforce through local education. Since the beginning, community college founders and advocates have supported access to higher education for those who had until then been denied or deemed unworthy based on race, sex, ethnicity, or socioeconomic status. ${ }^{1}$ Today, community and junior colleges continue that mission while also offering transfer opportunities, certificate options, and workforce development programs. Considering the ever-increasing costs of education and the snowballing student debt crisis, community colleges offer an incredible value: a high-quality education at a reduced cost. For many students, community college is the obvious choice, whether they are looking for a quick path to a career or to save money on a four-year degree.

In the 2016-2017 academic year, 38 percent of undergraduate students attended two-year public colleges and, according to the College Board, 59 percent of students at two-year public institutions graduate with absolutely no debt, a result of low tuition costs and flexible course schedules. ${ }^{2}$ Community colleges are about more than cost savings, however, and are very much about access. Evening, weekend, and online courses make college an option for those who work or support families, and most community college students do. In fact, about 80 percent of community college students work either full or part time. ${ }^{3}$ Most community colleges have open-door admissions policies, welcoming any student with a high school degree or equivalent. Many high school students are able to earn college credit at community colleges through dual-enrollment programs. Some have robust transfer programs and others are more career-focused; they are really quite diverse and so are their students.

Community colleges are known for providing access to education for historically underserved populations. Demographically, community colleges look different from most four-year schools. Fourteen percent of community college students are black and 22 percent are Hispanic. ${ }^{4}$ The average age of students is a little bit older at community colleges; 28 percent are 30 years or older. ${ }^{5}$ Some of these adults are going back to school after years in the workforce and some are going to college for the first time. Several community colleges are Hispanic Serving Institutions, a designation reached when the number of full-time equivalent students who identify as Hispanic reaches 25 percent or greater. ${ }^{6}$ Each student brings their own unique story with them to community college, resulting in robust class discussions, an emphasis on cultural awareness, and a rich learning experience.

Of course access and diversity are issues close to the heart of most librarians, meaning that work in a community college library can be especially fulfilling. More than a century after the first junior colleges opened their doors to those whom large universities had excluded, the modern community college continues to provide opportunity for historically underserved populations. Each student comes to community college with a story that, more than likely, includes facing adversity and overcoming barriers. The wide range of experiences and learning styles requires that community college librarians be especially tolerant, patient, and empathetic. Flexibility and open-mindedness are essential in community college libraries, as each patron interaction is unique from the next. Specific considerations facing community college librarians are explored below along with a reflection on how community college libraries are providing high levels of service despite some of the more obvious challenges they face.

\section{THE COMMUNITY COLLEGE REFERENCE LIBRARIAN}

Due to lower budgets, staff numbers in community college libraries are generally limited. Some smaller schools have just one or two librarians. Larger schools may have more librarians but duties are not always clear cut because the librarians wear many hats. In the community college library, it is quite common to encounter the Reference "and" librarian. For example, "Reference and Collection Development Librarian" or "Reference and Outreach Librarian" are common examples of job titles. Typically, each member of staff with such a title is required to serve time on the reference desk and teach classes while also focusing on other duties behind the scenes.

This also means that things like liaison work are not normally an option. There is rarely enough staff to designate each with a field or trade. Instead, community college librarians must be able to liaise with faculty and students in any field of study. Teaching information literacy classes often requires extra prep work if the librarian is not familiar with research in a given subject. This can be especially true of certain subjects. Nursing and allied health, for example, are among the most popular majors in the country, yet few librarians, community college or otherwise, have formal training in health sciences research. ${ }^{7}$ The community college librarian must always be willing to learn and develop new skills. Thankfully, since faculty at most community colleges are not required to conduct research or publish their work, almost all of a community college librarian's time can be devoted to student service.

\section{REDUCING ACCESS AND EQUITY BARRIERS}

Financial challenges are common among community college libraries; the average annual budget for a community college library is about one fifth that of four-year institutions. ${ }^{8}$ And with enrollment numbers expected to continue to decrease across the country, community colleges, and their libraries, are expected to offer a multitude of diverse resources and services with minimal funds. ${ }^{9}$ What's more, the students are facing their own financial challenges. Choosing a 
community college rather than a four-year institution does save students thousands of dollars, but more than half of community college students are low-income and 33 percent receive Pell Grants for low income students. ${ }^{10}$ The price of tuition alone is a barrier, never mind the added costs of transportation, course materials and technology tools. Therefore community college librarians must be creative to provide low-cost programs and services that benefit the library, the campus, and the students.

One example of such services is technology lending. Springfield Technical Community College in Springfield, Massachusetts, for example, has a laptop and wireless hot spot loan program. ${ }^{11}$ Thomas Nelson Community College in Virginia has a similar program. ${ }^{12}$ Students can borrow these items to work on research, assignments, or online courses. Other libraries loan tablets or e-readers for a similar purpose. These types of programs are beneficial to all involved. They provide services to students for whom the difference between passing and failing is internet access. These students might share their experience with friends, increasing library usage. And perhaps most importantly, access to these resources has the potential to improve student success and retention, something that benefits the college, the library, and the students.

Similarly, the open educational resources (OER) movement has seen significant traction and growth due to community college participation. The Community College Consortium for Open Educational Resources (CCCOER) has 88 member institutions. ${ }^{13}$ There are several institutions, such as Austin Community College and several California Community Colleges, that offer zero-textbook cost or "ZTC" degrees. Students in these programs do not have to purchase any textbooks while completing a ZTC degree and as a result save thousands of dollars in educational costs annually. ${ }^{14}$

Students are not the only patrons to benefit from the access provided by community college libraries. In some ways, community college librarians are a cross between public and academic librarians. After all, community colleges are public institutions_community institutions-and are therefore open to the public. Community college libraries have the opportunity to interact with the public in special ways and create programming that serves the surrounding communities. Because most students are non-residential, there is an emphasis on local collaboration; programming may include inviting local authors and artists to host talks or workshops. Many community college libraries host community events, collaborate with local public libraries, and loan local museum passes. They also serve public patrons with their collections, including sizeable popular fiction sections and consortia agreements with community libraries. Some community college libraries offer public computer access as well. The mission of community colleges is to educate the community, and librarians play an important role in making that education accessible.

\section{TEACHING INFORMATION LITERACY IN A COMMUNITY COLLEGE LIBRARY}

Due to the open-door admissions model at most community colleges, a typical classroom of community college students consists of a wide range of knowledge, experience, learning styles, and educational goals. The same classroom may have students who are new to the English language, students who already have an advanced degree, a student who wants to transfer to a four year school, a student who is only there to satisfy a job requirement, and so on. Community college students are often academically underprepared for the college experience; more than half enroll in developmental courses..$^{15}$ Thus, it is quite likely that the students in an information literacy session are completely new to research.

It's also common for students to struggle with digital literacy and access to the technology needed for academic success. According to the Pew Research Center, nearly half of US adults do not have internet access at home and only 17 percent of US adults consider themselves "digitally ready." 16 Not surprisingly, most of those who are "digitally ready" are white, higher income, and have a bachelor's degree or higher. ${ }^{17}$ A 2018 study of college students found that 20 percent did not have reliable access to technology, which resulted in lowered grade point averages. Students of color and students of low socioeconomic status were especially vulnerable. ${ }^{18}$

This diversity creates fascinating classroom dynamics but also poses a challenge to instructors. This is especially true in a one-shot information literacy class. If a librarian is only given one hour to teach a varied group of students about library services, the research process, citations, and so on, how does one make sure to reach every student? There is no right answer; librarians must consider their student population and community. Each class is different and requires considerable planning, which includes close collaboration with faculty. In my experience, there must be enough time for practice. Lecturing, learning activities, and group work can all hold a place in the classroom, but students need time to feel comfortable with library staff and systems, so handson experience is essential. This is why information literacy must span beyond the one-shot information literacy course.

Community college libraries must offer programming and activities that continue the conversation and offer support to students who did not absorb the information the first time. This can be done with citation and research workshops, online tutorials, one-on-one meetings with librarians, etc. These programs can be tailored for certain levels or student populations. For example, in a 2015 article, Katherine Turcotte suggests community college libraries offer specific services for adult learners like separate instruction classes that could minimize library anxiety and provide a foundation of knowledge of campus technologies like learning management software and Microsoft Office suite. ${ }^{19}$ Another study that focused on students with below-proficient information literacy skills suggests that librarians consider a better student-to-instructor ratio to provide students with guidance 
and feedback in the classroom. ${ }^{20}$ The methods used by community college libraries will depend on their specific student populations and the preferences of the instructors and librarians. But it is clear that there are often unique circumstances when teaching information literacy in a community college library that must be addressed.

\section{THE FRAMEWORK}

It is because of the uniqueness of community colleges that community college librarians often feel left out of major conversations surrounding information literacy at the college level. The specific needs of community college students do not always match the more general needs of the average college student because of the aforementioned gaps in knowledge, limited access to technology, etc. For this reason there has been some controversy surrounding the professional guidelines for teaching information literacy at the college level. Since the Association of College and Research Libraries (ACRL) began sharing drafts of the Framework for Information Literacy for Higher Education in 2014, the reaction from the library community has been varied. The creation of new standards in general triggers discomfort for many and, for some, the new framework feels abstract and perhaps a bit intimidating. This is especially true of community college librarians who feel that the Framework is beyond the grasp of students who are brand new to college research. A recent survey of librarians at private and public two-year institutions reveals that the Framework has not been easy to integrate into many community college instruction programs. ${ }^{21}$ Part of the challenge is time restraints; community college librarians cannot find the time to incorporate the ACRL Framework into their short, one-shot instruction sessions. ${ }^{22}$ In a national survey, 84 percent of librarians who responded expressed interest in professional development opportunities that focus specifically on using the Framework in community college libraries. ${ }^{23}$

But issues with the Framework run deeper; there are questions of where and how the Framework connects information literacy with social justice as well as the question of whether it should. ${ }^{24}$ Since social justice is a core value of community colleges, these questions are especially relevant to community college libraries and should be examined. The fact is, even five years later, it is still too soon to know the extent to which the Framework is being effectively utilized in community college library instruction. As it matures and develops, it will be necessary to conduct further investigation on implementation and success of the Framework in the community college setting.

\section{TRENDS ON THE HORIZON}

Just as any other library, community college libraries must keep up with changing trends and new developments in technology and academia. Community college enrollment is expected to decline in the coming years. ${ }^{25}$ This is partially due to reduced high school graduation rates caused by low birth rates during the last economic recession and also due to a boost in the economy (making the workforce, rather than college, an attractive option for adults). ${ }^{26}$ Colleges are responding by making their academic programs even more flexible via online learning options. As of fall 2017, 33 percent of college students are enrolled in at least one online course. ${ }^{27}$ In a 2012 report by the Online Computer Library Center (OCLC), community college librarians expect use of online library services to increase. ${ }^{28}$ As these trends continue, librarians will need to adjust their programs and services to meet the needs of online students. Embedded librarianship as well as digital information literacy initiatives are options to consider.

As mentioned previously, the OER movement is quite strong within community colleges. With recent reports of the merging of two major publishing companies, McGrawHill and Cengage, this is expected to continue as the options faculty have for proprietary course materials decrease or combine. Community college students, librarians, faculty and administration recognize the benefits of OER for student success and continue to advocate for implementation. OER is listed as the fifth highest strategic technology in "Higher Education's 2019 Trend Watch and Top Ten Strategic Technologies." ${ }^{29}$ Community college libraries make excellent support systems for campus-wide OER initiatives, and perhaps we will see more "Reference and OER" librarians in the future. Hopefully community college librarians will continue to find similar ways to promote positive change within their communities and beyond.

\section{CONCLUSION}

Community college libraries advocate and work for students; they not only offer resources and services that emphasize the importance of education, they also keep social justice at the heart of their mission by advocating for access and equity. I have experienced community college stigma as both a student and as a professional. I have been told that community college is easier than traditional four-year schools and that what I have to offer to the library community is not relevant. Whenever I face this type of stigma, I cannot seem to understand it. Even though community college libraries have unique populations and needs, fundamentally they exist for the same purpose as all libraries, academic or otherwise: to provide a high standard of service to their communities and beyond.

Of course, we do have differences, but why not see them as positive? Community college librarians are very fortunate because we get to have a direct impact on students who have been told via systems of oppression that they do not belong in college. As long as these systems exist, they will cause divisiveness and inequality. But community college libraries 


\section{INFORMATION LITERACY AND INSTRUCTION}

foster connection and promote inclusivity. I am calling on all librarians to support this mission and work together to find new ways to help our patrons succeed. Community college librarians have a lot to offer the library community-we also have a lot to learn. Who's ready to get started?

\section{References}

1. Richard L. Drury, "Community Colleges in America: A Historical Perspective," Inquiry 8, no. 1 (2003): 1-6, https://files.eric .ed.gov/fulltext/EJ876835.pdf.

2. Community College Research Center,"Community College FAQs," Columbia University Teacher's College, 2016, https:// ccrc.tc.columbia.edu/Community-College-FAQs.html; Jennifer Ma and Sandy Baum, "Research Brief Trends in Community Colleges: Enrollment, Prices, Student Debt, and Completion," College Board, 2016, https://trends.collegeboard.org/sites/default /files/trends-in-community-colleges-research-brief.pdf.

3. Community College Research Center, "Community College FAQs."

4. Community College Research Center, "Community College FAQs."

5. Community College Research Center, "Community College FAQs."

6. Hispanic Association of Colleges and Universities, "HACU Member Hispanic-Serving Institutions (HSIs)," January 10, 2019, http://www.ed.gov/about/offices/list/ope/idues/hsidivision.html.

7. National Center for Education Statistics, "The NCES Fast Facts: Most Popular Majors," Institute of Education Sciences, 2014, https://nces.ed.gov/fastfacts/display.asp?id=37.

8. IPEDS Data Center, "The Integrated Postsecondary Education Data System," National Center for Education Statistics, 2019, https://nces.ed.gov/ipeds/datacenter/Statistics.aspx.

9. Ashley A. Smith, "Community College Enrollment Rates Expected to Keep Falling," Inside Higher Ed, June 21, 2018, https://www.insidehighered.com/news/2018/06/21/community -college-enrollment-rates-expected-keep-falling.

10. Community College Research Center, "Community College FAQs."

11. Springfield Technical Community College Library, "STCC to Go!," Springfield Technical Community College, 2019, https:// libguides.stcc.edu/STCCtoGo/home

12. Hampton Campus Library, "Library Hotspot," Thomas Nelson Community College, 2019, https://libguides.tncc.edu/about/tech nology\#hotspots.

13. Community College Consortium for Open Educational Resources, "Members," Open Education Consortium, 2019, https://www.cccoer.org/about/members/.

14. California Community Colleges, "Open Educational Resources," 2011, http://extranet.cccco.edu/Divisions/AcademicAffairs/Open EducationResources.aspx; Austin Community College District, "Z-Degree," 2019, https://www.austincc.edu/academic-and-career -programs/z-degree?ref=spotlight.

15. Monica Anderson, "Digital Divide Persists Even as LowerIncome Americans Make Gains in Tech Adoption," Pew Research Center, March 22, 2017, https://www.pewresearch .org/fact-tank/2017/03/22/digital-divide-persists-even-as-lower -income-americans-make-gains-in-tech-adoption/.

16. John B. Horrigan, "Appendix: Detail on Digital Readiness and Other Metrics across Groups," Pew Research Center: Internet, Science \& Tech, September 20, 2016, https://www.pewinternet .org/2016/09/20/appendix-detail-on-digital-readiness-and-other -metrics-across-groups/.

17. Horrigan, "Appendix."

18. Amy L. Gonzales, Jessica McCrory Calarco, and Teresa Lynch, "Technology Problems and Student Achievement Gaps: A Validation and Extension of the Technology Maintenance Construct," Communication Research, August 31, 2018, https://doi.org /10.1177/0093650218796366.

19. Katherine A. Turcotte, "Helping the Adult Learner Succeed: How Community College Libraries in Massachusetts Are Serving This Growing Population," Library Philosophy and Practice, 2015, https://digitalcommons.unl.edu/libphilprac/1264/.

20. Don Latham and Melissa Gross, "Instructional Preferences of First-Year College Students with Below-Proficient Information Literacy Skills: A Focus Group Study," College \& Research Libraries 74, no. 5 (September 1, 2013): 430-49, https://doi.org /10.5860/crl-343.

21. Susan T. Wengler and Christine Wolff-Eisenberg, "Community College Librarians and the ACRL Framework: Findings from a National Study," College and Research Libraries, 2019, https:// academicworks.cuny.edu/qb_pubs/56/.

22. Wengler and Eisenberg, "Community College Librarians and the ACRL Framework."

23. Wengler and Eisenberg, "Community College Librarians and the ACRL Framework."

24. Anderew Battista et al., "Seeking Social Justice in the ACRL Framework," Communications in Information Literacy 9, no. 2 (2015), https://files.eric.ed.gov/fulltext/EJ1089152.pdf; Laura Saunders, "Connecting Information Literacy and Social Justice: Why and How," Communications in Information Literacy 11, no. 1 (2017): 55-75, https://files.eric.ed.gov/fulltext/EJ1148869.pdf.

25. Smith, "Community College Enrollment."

26. Smith, "Community College Enrollment."

27. National Center for Education Statistics, "Enrollment and Employees in Postsecondary Institutions, Fall 2017; and Financial Statistics and Academic Libraries, Fiscal Year 2017 First Look (Provisional Data)," Institution of Education Sciences, January 2019, https://nces.ed.gov/pubs2019/2019021REV.pdf.

28. Online Computer Library Center, "A Snapshot of Priorities and Perspectives," 2012, https://www.oclc.org/content/dam/oclc /reports/us-libraries/214758usb-c-A-Snapshot-of-Priorities -and-Perspectives.pdf.

29. D. Christopher Brooks and Mark McCormck, "Higher Education's 2019 Trend Watch and Top 10 Strategic Technologies," EDUCAUSE, January 28, 2019, https://library.educause.edu /resources/2019/1/higher-educations-2019-trend-watch-and -top-10-strategic-technologies. 